\title{
Telling stories: engaging critical literacy through urban legends in an English secondary school
}

\section{Abstract}

Non-dominant voices have been further marginalised in the most recent National Curriculum in England (DfE 2014) and those working across the English teaching profession often find the subject framed according to narrow, assessmentdriven models and prescribed skill sets. This article brings together two perspectives on the importance of literacy education that remains rooted in young people's everyday experiences of place. Katie is a newly qualified secondary English teacher. She will share examples taken from her own classroom practice of the ways in which she has responded to stories told by young people about the places in which they live. Susan is a tutor of Initial Teacher Education (ITE). She suggests that Katie's approach provides persuasive exemplification of how engagement with alternatives to a dominant view of literacy should remain a key objective for those working with beginning teachers of English. For Katie's students, urban legends are powerful texts which offer the means to explore what we do when we tell stories, both inside and outside the English classroom. As will be shown, such stories are telling examples of the resources young people can bring to critical literacy learning in current classrooms. In the context of the dominance of a narrow, mandated experience of English as a subject, the imperative becomes even greater to recognise stories such as those shared by Katie's students as opportunities for authentic, creative and critical engagement with text.

\section{Key words}

critical literacy; English teaching; curriculum English; early career teaching

\section{Introduction}

Beginning and early career teachers of English navigate a challenging landscape where they work to develop critical, research-informed practice within the wider context of a mandated curriculum in which their subject is increasingly framed according to narrow, assessment-driven models and prescribed skill sets. In England, non-dominant voices have been further marginalised in the latest iteration of the National Curriculum English Programme of Study (DfE 2014), with its emphasis on canonical 
texts of 'British heritage' and the side-lining of speaking and listening as core elements of the curriculum. Within this context, this article brings together the perspectives of a teacher of English at the beginning of her career [second author] and a tutor of Initial Teacher Education (ITE) [first author] to argue for the continued importance of literacy education that develops young people's critical engagement with text, rooted in their everyday experiences.

We first outline the key principles that inform our approach to literacy education. These form part of the theoretical framework which beginning teachers of English on ITE courses at the University attended by [second author] are invited to explore as part of their work in classrooms. [Second author] then shares examples from her practice as a beginning and newly qualified teacher to illustrate how she brought together theory and practice in her own classroom. She uses stories told by young people in and about the places in which they live as resources for developing critical literacy. In doing so, her students are offered the opportunity to critically explore what it means to tell such stories. We argue that [second author]'s approach is an example of a dynamic alternative to dominant models of literacy and the essentialising of texts worthy of study.

\section{A story of critical literacies}

Subject English has been the focus of debate for decades, but recent years have seen the particularly acute impact of neoliberal policy on the experience of learners and teachers in English classrooms. Increasingly driven by a climate of intense performativity, the subject has been reduced to that which can be measured by standardised assessment. Competency-based assessment regimes, such as that described by Locke (2008) in the New Zealand context, are responsible for 'distorting students' understandings of genre, marginalising real-world textual practices [...] and drilling students in arid and formulaic responses to literary texts' (p. 308). Alongside this, as is documented by Allard and Doecke (2014), the standards agenda frames the work of teachers across a range of jurisdictions. The impact of this policy context on experienced teachers has been outlined in various international contexts (e.g. Sandretto and Tilson, 2015; Comber, 2012; Ravitch, 2010; Ball, 2003). However, the particular experience of teachers new to the profession in navigating this landscape is also a concern. McIntyre and Jones (2014) describe the experiences of beginning and newly qualified teachers of English and the potential of ITE as a critical space for the negotiation of 
possibilities amongst the apparent limitations of policy. For the teachers in their study, English in schools took on a formulaic approach with a narrow sense of the texts available to study and a set range of genres with which pupils could engage in their own writing. Turvey and Lloyd (2014), through a powerful account of a beginning teacher's exploration of learning rooted in the social relationships of his English classroom, argue that "'subject knowledge" in English should not be seen as a stable, pre-existing entity and the disposition towards this body of knowledge something that has been "settled" before entry into teaching' (p. 77). Exploring the impact of dominant discourses around literacy on the understanding and practice of teachers, Sandretto and Tilson (2015) note that such understanding and practices can 'reiterate and/or resist the discourse of education policies' (p. 1, italics in original). Indeed, Allard and Doecke (2014) describe early career teachers' negotiation of their professional knowledge and values, the mandated curriculum, and the standards by which they themselves are measured in their practice; the authors share examples of teachers 'marshalling [their] knowledge against those standards' (p. 42, italics in original) in developing practice which challenges the restrictions of a standardised curriculum. In doing so, they are shown, paradoxically, to be demonstrating how drawing upon diverse experiences in the classroom does in fact meet the objectives of a teachers' standards agenda.

This article offers a case study of one beginning teacher's challenge in finding a space for learning which, as Lankshear and Knobel (2011: 253) note, 'maintains points of connection to human lives as trajectories in ways that are often lost by hiving off formal education into contrived spaces, time frames and idiosyncratic ways of doing things'. The practice described by [second author] underlines the power of vernacular texts as resources in developing rich and broad sets of literacy skills and the recognition of voices marginalised in many pedagogic contexts (Garcia and Morrell, 2013). As Maybin (2013) highlights, in many ways responses to vernacular texts meet the criteria of mandated assessment, but also demonstrate skills which are developed, and have value, in lives beyond the English classroom.

The work undertaken by [second author] in her classroom is informed by a conception of literacy that emerges from critical reflection upon the theoretical models with which she engaged on her ITE course. This conception of literacy is broad; within it, literacy includes digital, visual and material resources and literacy education involves a focus on supporting creative and resourceful responses to a range of contexts 
(Sandretto and Tilson, 2015; Lankshear and Knobel, 2011; Pahl and Rowsell, 2006). Importantly, while the emphasis in contemporary English classrooms is on young people being assessed on an individual skill set, this model of literacy also includes participatory, collaborative and intergenerational practice and a strong emphasis on the local and the transformative potential of place-based pedagogies (Comber, 2016; Garcia et al, 2015; Jones and McIntyre, 2014). Underpinning this position is an understanding of literacy practices as inherently social actions: 'things which people do, either alone or with other people, but always in a social context - always in a place and at a time' (Barton and Hamilton 1998, 23).

Within this framework, [second author] has been particularly interested in the work of Gonzalez and Moll (2005), and in bringing a broader range of children's cultural experiences into the classroom to support learning. The approach she describes here is based on storytelling and oral culture, both of which are prominent in seminal depictions of local literacy practice (e.g. Street, 1984; Heath, 1983) and have been recognised as key resources in young people's critical place-making work (Kinloch, 2010). [second author]'s work draws on the notion that communal stories can preserve the values of past generations or cultures (Nathanson, 2006) and can reveal much about current society through the ways in which they are retold.

[second author] utilises the stories her students tell each other in and about the places in which they live as a resource to engage in literacy as a critical practice, recognising that literacy involves 'reading the word and the world' (Freire, 1987). Freire advocates pedagogies which are based on key concepts, including raising the critical consciousness (the conscientização) of learners and placing dialogue at the heart of learning, with teachers and students acting as partners in the process and recognition of prior knowledge. Comber's (1994) work on critical literacy offers three key tenets that are useful for this discussion. The first involves repositioning students as researchers of language; second, respect for student resistance and exploring minority culture constructions of literacy and language use; and third, problematising classroom and public texts. As [second author] will go on to outline, each of these tenets is evident in her approach. For the learners in her classroom, telling stories is a way to build understanding that literacy is not a neutral technology (Larson and Marsh, 2005; Hagood, 2002). Rather, it is shaped by dominant forces and, in turn, shapes subjects and discourses (Freebody and Luke, 1990). Critical literacy relies on the ability 
to view all texts (including multimodal texts) as constructs with at least one purpose and techniques for achieving this. Meek (2011: 10) describes this kind of literacy as 'a supercharged model, which allows its possessors to choose and control all that they read and write'. According to Hagood (2002: 249), 'critical literacy aims to effect change and to form a more socially just and equitable society through literacy users' scrutiny of relations between and among language, literacy, meaning, and power'. Developing learners' understanding of this is therefore an important aspect of the work of a teacher towards social justice (Luke, 2014).

Given a teacher's responsibility for delivering a mandated curriculum, the challenges of engaging with this model of literacy are not inconsiderable. Masuda (2012) describes the ways in which a critical literacy approach to the teaching of reading 'can become a site for struggle over [...] competing teacher identities' ( $p .220$ ) as shaped by dominant discursive models. For the teachers in Masuda's study, 'the discourses of critical literacy posed overt contradictions' ( $p$. 229) which are taken up in the active negotiation of their work as professionals. For a beginning teacher in particular, the challenge of engaging with a critical literacy approach sits within a broader framework of assessment against national Teacher's Standards (DfE, 2012) as well as protecting the integrity of a burgeoning professional identity, within which the negotiation of such challenges can play a key part. As [second author] will go on to outline, however, developing a curriculum which fosters critical literacy is something to be done whilst also meeting the needs of the National Curriculum and the expectations of developing students' skills to succeed in external examinations. Vasquez (2004: 27) recognises the challenges posed when working with even the youngest pupils; in her case, they are of kindergarten age: 'while my students and I negotiated a critical literacy curriculum, we were not free from curricular mandates and the threat of standardised testing.'

For Vasquez, working to develop a critical literacies approach emerges from a recursive process. This begins with developing a conceptualisation of the possibilities offered by working with learners' cultural and semiotic resources. This then feeds into the active and collaborative negotiation of curriculum spaces, within which students draw on these resources and are supported to develop critical literacy skills. As Vazquez notes:

'In my experience, the extent to which I was able to negotiate space to engage in critical literacy practices was related to the 
extent to which I had understood possibilities for engaging in critical literacies' (ibid: 31).

Along this model, the process described by [second author] is both underpinned and driven further by her own learning and reflection. In contrast to a curriculum which essentialises subject English as definable content and measurable skills, we argue that a critical literacies approach is based on dynamic engagement. This is fundamental for the development of sustainable critical pedagogies which can work within and beyond the boundaries of mandated learning.

Our article comes together as a result of [second author]'s on-going critical inquiry into this aspect of her practice and our on-going conversations, throughout her ITE course and her year as a Newly Qualified Teacher (NQT), about how this has fed into her development as a teacher of English. These were two years during which [second author]'s practice was regularly assessed against the Teachers' Standards (DfE 2012), firstly in order to meet the requirements of Qualified Teacher Status as part of her ITE year, and then during her probationary NQT year. This context is significant when considering the decisions made by [second author] in order to engage and support the learners in her English classroom. Whilst representing a key part of the mandated landscape to be navigated as a beginning and early career teacher, as Allard and Doecke (2014: 44) note, the 'quality/ effectiveness' agenda by which [second author], and all teachers, are measured does in fact reflect, 'an understanding that teaching is an on-going process of learning, and of developing problem-solving skills on the basis of context and in response to particular student needs'.

[second author] takes up her own story from here, outlining how she has approached this aspect of her practice firstly as part of her studies during her ITE year, and subsequently in her NQT classroom. She presents examples of the responses of her students and, through these, examines the affordances of urban legends as resources for critical literacy education. We then draw together the wider implications for those working in literacy and teacher education.

\section{Urban legends and a critical literacy curriculum: the research}

The initial inspiration for using urban legends to develop critical literacy was kindled by two critical incidents (Tripp, 2011) during my ITE course. 
The first incident occurred during research I conducted into students' literacy practices in and out of school. During one interview, a Year Seven boy (aged 11) stated firmly that being able to read was important, but stories were not. His comment surprised me as he would frequently share stories with friends about events at home or in the local area. Despite this, he did not seem to think that the kinds of literacies involved in storytelling were important or empowering. In my observations of English lessons thereafter I focused upon the nature of the texts that were used and valued by teachers and students.

The second incident occurred while I was observing a year 9 English lesson (students aged 13-14), including a group of students deemed to be of 'low ability'. Students were attempting to arrange slips of paper, on which phrases were printed, in order to construct sentences. Spontaneously, a student told a story that she had heard about a clown who was scaring people in the local village and the other students began to question her for more details. Before they could further interrogate or criticise the story, the teacher redirected them back to the task of physically constructing sentences. This resonated with me as an apt display of how teachers might fixate upon the more measurable writing skills which current GCSEs test, at the expense of exploring the oral storytelling which students naturally take part in.

Following these incidents, I focused my ITE coursework on how teachers can validate students' own stories as texts within the English classroom whilst building critical literacies in a context that is relevant to students' experience of language. Crucially, I also sought to raise students' awareness of their power as storytellers.

Out of the variety of stories which students told, I was particularly interested in those categorised as 'urban legends'. This term refers to modern folklore or myths which are frequently shared verbally, in the press or on social media. The attraction of these stories for students, and, by extension as a teacher, is that they are sensational, shocking and frequently explore provocative topics. They are typically grounded in a place that is local to students in some way, including online spaces, but they can be national stories which have become localised. For example, the student's clown story mentioned above was a variant of the real episode of the 'Northampton clown' reported in newspapers: 
"An unnerving, anonymous clown has sent shivers down the spines of Northampton residents by lingering on street corners in full fancy dress, for three nights in a row" (Metro, 2013).

The student's retelling, however, set the tale in the school's immediate vicinity.

The work was undertaken on my teaching practice placement, and subsequent NQT year at a secondary school in an ex-mining village in Derbyshire, England. Both classes were Year Nine (ages 13-14) mixed ability groups of 21 students each, ranging from predicted grades for GCSE English of A*-E. All students spoke English as their first language. I worked with the first class (Class A) over four consecutive lessons, collecting data comprising of student's written work which was a mixture of analyses, creative writing and reflections. Using the local clown legend as a starting point, I formed an outline of activities which would allow for critical literacy practices. The following year, I adapted these lessons for use with a different mixed ability Year Nine group (Class B). This time, I recorded the discussions about urban legends on my iPad, which I carried around the classroom. Dialogue about the potential of urban legends for learning was central to the approach I took, and students were aware of my interest in their responses and how I hoped it would inform their lessons. Informed consent was gained to allow me to generate data from their classwork, according to the ethical procedures of the school and of educational research more broadly (BERA, 2011). I have employed pseudonyms throughout the reporting of the work which follows.

In the first lesson with Class A, students discussed local legends such as that of the school ghost, shared legends which they had heard and lastly considered why people tell urban legends. After this lesson, they progressed to reading and analysing a story I had written myself, called 'Watching', which was a retelling of the Northampton clown urban legend.

This version began with a sinister atmosphere and deliberately misled the reader to assume the main character has violent motives:

'At last, he arrived at number thirty-one. Reaching into his pocket, his fingers brushed on something cool and metal. He withdrew his hand sharply. Not now, it'd be too obvious.' 
Through gradually more detailed descriptions, it is revealed that the man is a clown, not a murderer, and the metal object is simply a horn. The story ends by showing the character's tragic backstory: how he has lost his family and seeks to make children smile to help himself through the grief. It demonstrated how stories can be retold in a new way in order to achieve a particular purpose; the purpose in this case was to make the reader consider that the legends they hear might misrepresent the truth.

As a model of storytelling, 'Watching' also demonstrated how carefully chosen vocabulary can deliberately manipulate the reader. For instance, students discussed the effect of the word 'sharply' to describe the clown's movement around the 'cool and metal' object in his pocket, actually the horn. The story showed how a writer can unveil a character's identity for effect and use red herrings, whilst also modelling how students might vary their sentence structures and use creative techniques.

Students then considered how they too might reinterpret an existing myth (which they had researched as homework) for their own purposes and they started to plan and write their own retellings. For example, one student, Tim, wrote a story called 'Arrow' in which a modern-day Robin Hood was revealed to be a villain rather than a hero. Mimicking the techniques in my story, he attempted to disguise the identity and true intentions of the main character until the end of the story:

'I quickly pulled out a long metal item and placed it into the holster and let it fly. The sharp tip pierced his rightshoulder blade and he dropped to the floor [...] Oh and by the way the name is Arrow but my real friends know me as the Hooded Arrow.'

Students wrote a rationale explaining the decisions they made when planning and writing their stories and the effect they had hoped to achieve on the reader. For his rationale, Tim wrote: 'I decided to change the legend by making Robin Hood a murderer' and 'The message I wanted my reader to take from the story is that not everything you hear is $100 \%$ true.' Another student wrote of their story: 'I changed the story so that the clown was really his dad who wants to spend time with him. I wanted to make people understand that the stories they hear might not be completely true.' 
In the time before the final lesson, I uploaded students' stories onto a website alongside a picture of the student's choosing. This would allow students to share their stories in a way that mimicked how they shared stories online outside of the classroom. I had initially hoped to put these stories on a Facebook page where they might be shared and discussed in the same environment as existing urban legends; as Lankshear and Knobel note, teachers must be aware of the 'costs of separating learning from authentic contexts of knowing' (2011: 213). However, due to the school's policy on the use of Facebook, the stories had to be put onto a website instead, where comments were unavailable. As an alternative, students wrote their comments about each other's stories on paper and shared these at the end of the session. Prompted by questions, students wrote observations such as:

'People shouldn't share this story because this could perhaps scare people when it's not exactly true.'

'People might share this story because they might also have been bullied and the end is comical.'

'I would retell this story to scare people.'

'I wouldn't retell this story because I think it's unrealistic.'

Before students returned to the main curriculum work, I asked them to write a reflection about whether they thought it was important to learn about urban legends. One response was: 'I think it is important to learn about urban legends so we aren't fooled by them in the future and so we can prevent others from falling into their trap.' Overall, students responded in a similar way to this. Whilst a small number of students argued that we should not learn about urban legends because they are not true and people might believe them, these responses still demonstrated an understanding of the power that urban legends hold. However, as Peim (1994: 65) suggests in relation to critical theory and the English classroom, as long as alternative ways of viewing literacy learning remain within the 'sphere of the incorporated' rather than being 'centrally informative [...] they remain, effectively, marginalised'. I continued to reflect, therefore, according the recursive model outlined above, on the ways in which a critical literacies approach could be negotiated in my NQT classroom. 
The lessons with Class B used similar activities of discussion and analysis, but due to time constraints we had less space for rewriting urban legends. The first discussion lesson began with only the words 'Bloody Mary' on the whiteboard. This refers to an urban legend in which a person who says 'Bloody Mary' three times whilst looking in a mirror will cause a woman to appear with potentially dangerous consequences. This story was one that I had heard myself in primary school and then as a teacher had also heard students sharing it. The following conversation ensued immediately after I wrote the words 'Bloody Mary' on the whiteboard:

Teacher: Have you ever said that three times in a mirror?

Alice: Miss, have you ever said Candyman in a mirror?

Teacher: No, what happens?

Alice: I don't know-

Beth: Yeah you say- you- apparently you switch your lights off and you shut your door-

Chloe: And you need to be alone-

Beth: And you need to be alone and you go to the mirror and you say 'Candyman, Candyman, one, two, three', turn around three times and then look in the mirror and Candyman's there. I tried it all the time in primary.

The girls shared the storytelling role, correcting each other using their individual knowledge of the version of the legend most familiar to them. Beth paused and corrected herself to add in the word 'apparently', a tentative storytelling approach which was used by many other students in the lesson. When Darren told his version of the school ghost legend, students noticed how there were similarities between the legends that they had heard in different schools:

Darren: Apparently like someone was getting married in this school and they tripped down the stairs and died or something. On their wedding day. And then they're a ghost in the school in that bit that's under student services.

Teacher: Who else has heard that? Do you believe it?

Beth: I was told it in my old school!

Alice: I did.

Teacher: You heard the same story in your old school?

Alice: Apparently there's a bell tower on top of the school and it was believed this woman died there and she was stood up there looking at you... and she was in the toilets. 
Beth: Everyone used to say there was a green lady in the girls' toilets.

Teacher: Here?

Beth: No, in my old school, in this one cubicle.

The way that students began their stories using 'apparently', 'it was believed' and 'everyone used to say' revealed an awareness of their role as storytellers and a feeling of responsibility for the language they chose when sharing their stories. Interestingly, these careful openers were used much less after we moved from whole class discussion to smaller groups. In front of the class, students seemed more aware of their audience and appeared to be protecting themselves from criticism by using these statements.

I asked students why they thought people shared these kinds of stories and their answers included to scare people, get attention, stop a person from doing something, to entertain people and to become popular. Students were then given a selection of written urban legends, such as emails, letters, text messages and forum posts, to read, discuss and make notes on in groups. They excitedly indicated any that they had heard before and whilst moving around the classroom I found it difficult to keep up with the number of students who wanted to tell me the different versions that they knew of these legends. One student even stayed behind after the class finished to tell me a legend that she had heard. The conversation in groups was enthusiastic and took on an evaluative quality. Darren was heard calling proudly across the classroom to another student 'I heard a different version of that one which is way better.'

Another student, Eddie, particularly seemed to disapprove of the legends, commenting with disdain that 'It just seems made up, like for effect.' In previous lessons on fiction texts, Eddie had never complained that Ray Bradbury's, Charles Dickens' or any other author's stories were just 'made up for effect'. He stated dismissively about the urban legends: 'I don't read this stuff'.

Following this, students considered multiple versions of the same urban legend, often referred to as 'The Foiled Abduction', which began in the 1980 s and is still shared today. We discussed how it had changed in its retellings, for example the different details, language and the forms that the legend took. Darren commented that it shows how 'they evolve' whilst 
Eddie thought it 'shows the generation gap, like you go from the police to an email to Facebook'.

In the next lesson, we focused more closely on the language that urban legends use. To do this, students reread one of the legends from the previous lesson which was a chain email about a murder. At the end of the email was a paragraph in which the writer tried to persuade the reader to forward the email and share the story. Using a grid which broke this paragraph into sections, students analysed the language by suggesting the effect of words and phrases. This is a method I had previously used with other students for planning assessed pieces or revising for examinations. However, despite the different choice of text, their responses demonstrate the same depth of analysis:

'emphasises how the man was "never caught" \& makes the reader think the murderer is waiting for them'

"'you" - direct address like its definately [sic] going to be you who will also suffer the same.'

'"do not" - agression [sic], commanding you to do what it says.'

Students confidently explored the tone of the piece, its techniques and how they achieve the author's purpose.

In a conclusion to the topic, I asked students to write down their thoughts on how urban legends might be used for teaching. Responses varied: a small number of students like Eddie dismissed the stories: 'They're just not true so why would you teach them?' When I suggested that the novels we read in class are also not true, these students sought to argue what they thought real literature was and why urban legends were not worthy of study. Other responses expressed interest in the history and social effects of urban legends; one student wrote:

'These types of stories could be used to teach children that not all stories everyone sends you is true but also it teaches you to understand that some could have a very special message in every different one. It could show people how long the stories have been going on for and also how much they change through the years but it teaches you not to lie or tell tales to scare people.' 


\section{What can we tell about critical literacy learning through urban legends? Some reflections}

For [second author]'s students, urban legends are powerful texts which offer the means to explore what we do when we tell stories, both inside and outside the English classroom. Stories such as those shared by [second author]'s students represent opportunities for creative and critical engagement with text; as such, they are telling examples of the resources young people can bring to critical literacy learning in current classrooms.

We argue that these are 'telling' stories in many ways. Not only are the stories themselves representative of alternative, often marginalised, experiences, both they, and the process of negotiating a curriculum based upon them, represent a challenge to the system of knowledge represented by a narrow, competency-driven curriculum, placing the voice of learner and teacher at the heart of the literacy learning experience. Urban legends draw attention to the valuable learning opportunities and resources that currently lie outside the mandated English curriculum. They reveal the ways in which students can engage with community resources through a critical literacies approach whilst practising the skills esteemed by the National Curriculum. These stories can benefit teachers and learners by 'grounding learning in situated practices where participants learn to do and be in purposeful ways' (Lankshear and Knobel, 2011: 253). The potential of using community resources extends to the possibility of work which is focused outside the classroom, or which invites members of the community into the classroom to become involved in the sharing of stories and coconstruction of local knowledge (Jones and McIntyre, 2014; Comber, 2016).

The benefit of using urban legends in the classroom was evident from the first moments of these lessons when Class A were asked about the school ghost and Class B about Bloody Mary. Students instantly engaged with the topic, asked questions and enthusiastically sought to share their own stories, showing how children are natural and experienced storytellers (Heath, 1983) but also, given the right context, also open to the interrogation of such stories and their place in their everyday language use (Baker-Bell, 2013). The reason for their motivation is perhaps due to the direct relevance of these texts to students' lives. The majority of legends that students shared concerned people or places of significance to the students, or had been told by people or in places that had value to 
the student. From family, friends, social media, teachers or scout camps the range of sources demonstrated just how ubiquitous these legends are in students' lives. By drawing on these resources, we take a 'funds of knowledge' approach which both values and 'represents communities in terms of resources' (Gonzalez and Moll, 2005: x). Learning builds on and develops students' current understanding of the world around them, in a way that is meaningful to them.

Lankshear and Knobel (2011) emphasise the importance of 'pull' learning, where students are driven to explore as opposed to a 'push' approach of programme-based learning. Using urban legends allowed for what Vasquez (2004: 32) refers to as a 'generative' approach, whereby students guide the learning through their queries and experiences. This sense of ownership allows for organic connections to be made to other texts: with both classes the first urban legends examined were fantastical horror stories, but students made links to news topics and other nonfiction texts that they had encountered. This allowed students' learning to extend into their everyday experience of language; as Darren demonstrated when he commented that 'it's like the stories your parents tell you to make you stop doing stuff'. Comber's (1994) tenets of critical literacy are exemplified in students' active roles as researchers of language and in the foregrounding of vernacular texts which represent their everyday practice. The problematising of classroom and public texts is also evident in Eddie's observation that the urban legends were 'just made up for effect' showing a further critical understanding of the way that these stories are constructs using language to achieve a desired effect. The ease with which Eddie identified this may be due to the less carefully constructed nature of urban legends and so their devices can be more obvious to identify. Whilst some might argue that the simple vocabulary and structure of many urban legends offer poor examples of storytelling, this makes them an ideal starting point for developing critical literacy skills which can then be applied to more complex texts. More complex vocabulary can still be introduced as part of meaningful discussions around these urban legends.

As Maybin (2014) and Vasquez (2004) have made evident in their work, it is possible to meet the needs of the mandated curriculum and preparing students for future external examinations through the approach developed in [second author]'s classroom. Urban legends offer many opportunities for rich language analysis and the development of creative writing, as demonstrated by Class A's creative retellings of stories and Tim's use of writerly techniques to build tension. 
The critical literacies approach taken by [second author] has also allowed her to navigate a professional identity within a context where she herself is being assessed. She has found a space within her classroom to resist the shaping of her pedagogic understanding and practice by a narrow mandated model (Sandretto and Tilson, 2015). As such, her experience echoes that reported by Masuda (2012: 225), who argues that teachers who have taken up a critical literacies approach can be seen to have 'repositioned themselves as teacher subjects with power by holding themselves accountable to their teaching, rather than as powerless technicians held accountable by external standards'.

[second author]'s work suggests the importance of supporting those entering the profession to engage with alternatives to a dominant view of literacy and the current context for the subject means an even greater imperative that this should remain a key objective for those working with beginning teachers of English. Those working to find spaces within their practice to challenge dominant models equally offer a valuable resource for developing understandings of the lived realities of education policy, as well as the potential for change embodied within critical literacy practice. As Comber (2016: xix) points out, collaborative research with teachers 'can unleash alternative imaginings, practical optimism in the face of real despair - small beginnings of new conversations, new ways of knowing and more hopeful action'.

As a beginning teacher, [second author] found her understanding of the potential of critical literacy practices deepened as a result of the work she has outlined in this article. In turn, this has helped her to negotiate further spaces in her classroom for developing students' critical literacy within the mandated curriculum (Vasquez 2004), allowing her to explore and engage with the range of resources provided by the students and their community, contributing to her fundamental aim of making classroom learning meaningful for students.

\section{References:}

Allard, A. and Doecke, B. (2014) 'Professional knowledge and standardsbased reforms': learning from the experiences of early career teachers' English Teaching: Practice and Critique, Vol. 13, No. 1, pp.39-54

Baker-Bell, A. (2013) '"I Never Really Knew the History behind African 
American Language": Critical Language Pedagogy in an Advanced Placement English Language Arts Class,' Equity \& Excellence in Education, $46: 3,355-370$

Ball, S. (2003) 'The teacher's soul and the terrors of performativity', Journal of Education Policy, Vol. 18, No. 2, pp. 215-228

Barton, D. and Hamilton, M. (1998) Local Literacies. London: Routledge

BERA (2011) 'Ethical guidelines for Educational Research', available at: https://www.bera.ac.uk/researchers-resources/publications/ethicalguidelines-for-educational-research-2011 (last accessed February 4th 2016)

Comber, B. (1994) 'Critical literacy: an introduction to Australian debates and perspectives', Journal of Curriculum Studies, vol. 26, no. 6, pp. 65566

Comber, B. (2012) Mandated literacy assessment and the reorganisation of teachers' work: federal policy, local effects. Critical Studies in Education, 53 (2) 119-136.

Comber, B. (2016) Literacy, Place and Pedagogies of Possibility. Routledge: New York \& London

Department for Education (2012) Teachers' Standards available at: https://www.gov.uk/government/uploads/system/uploads/attachment_da ta/file/301107/Teachers Standards.pdf (last accessed February 4th 2016)

Department for Education (2014) National Curriculum in England, available at: https://www.gov.uk/government/publications/nationalcurriculum-in-england-english-programmes-of-study (last accessed February 4th 2016)

Metro (2013) 'Not funny: Creepy clown lingers on streets of Northampton in middle of the night', available at: http://metro.co.uk/2013/09/15/notfunny-creepy-clown-lingers-on-streets-of-northampton-in-middle-of-thenight-4012455/\#ixzz46InU5KVz last accessed April 20th 2016

Freebody, P., \& Luke, A. (1990). 'Literacies programs: Debates and demands in cultural contexts'. Prospects 5(3) 7-16.

Freire, P. and Macedo, D. (1987) Literacy: Reading the word and the world. Westport, CT: Bergin and Garvey 
Garcia, A. and Morrell, E. (2013) 'City youth and the pedagogy of participatory media', Learning, Media and Technology, 38:2, 123-127,

Garcia, A., Mirra, N., Morrell E., Martinez, A. and Scorza, D. (2015) 'The Council of Youth Research: Critical Literacy and Civic Agency in the Digital Age', Reading \& Writing Quarterly, 31:2, 151-167

Gonzalez, N., Moll, L. C. and Amanti, C., (2005) Funds of Knowledge: Theorising Practices in Households, Communities and Classrooms. London: Routledge

Hagood, M. C. (2002) 'Critical literacy for whom?' Reading Research and Instruction, 41:3, 247-265

Heath, S. B. (1983) Ways with Words. Cambridge: Cambridge University Press

Jones, S. and McIntyre, J., 2014. 'It's not what it looks like. I'm Santa': connecting community through film'. Changing English. 21(4), 322-333

Lankshear, C. and Knobel, M, (2011) New Literacies - Third Edition. Milton Keynes: Open University Press

Larson, J. and Marsh, J. (2005) Making Literacy Real: Theories and Practices for Learning and Teaching. London: Sage

Locke, T. (2008) 'English in a Surveillance Regime: Tightening the Noose in New Zealand', Changing English, 15:3, 293-310

Luke, A. (2012). 'Critical literacy: Foundational notes'. Theory into Practice, 51 (1), 4-11.

Masuda, A. (2012) 'Critical Literacy and Teacher Identities: a discursive site of struggle', Critical Inquiry in Language Studies, 9 (3) 220-246

Maybin, J. (2013) 'What counts as reading? PIRLS, Eastenders and The Man on the Flying Trapeze', Literacy 47 (2) 59-66

McIntyre, J. and Jones, S., 2014. 'Possibility in impossibility? Working with beginning teachers of English in times of change English in Education' 48(1), 26-40 
Meek, M. (2011) On Being Literate. London: Random House

Nathanson, S. (2006) Harnessing the Power of Story: Using Narrative Reading and Writing Across Content Areas. In: Reading Horizons, 47 (1) $1-26$

Pahl, K. and Rowsell, J. (eds.) (2006) Travel Notes from the New Literacy Studies: Instances of Practice. Clevedon: Mulitlingual Matters

Peim, N. (1993) Critical Theory and the English Teacher: transforming the subject. London: Routledge

Ravitch, D. (2010) The Death and Life of the Great American School System: How Testing and Choice Are Undermining Education Basic Books: New York

Sandretto, S. and Tilson, J. (2015) 'Discursive constructions of literacies: shifting sands in Aotearoa New Zealand' Discourse: Studies in the Cultural Politics of Education, doi:10.1080/01596306.2015.1075472

Street, B. (1984) Literacy in Theory and Practice. Cambridge: Cambridge University Press

Tripp, D. (2011) Critical Incidents in Teaching. London: Routledge

Turvey, A. and Lloyd, J. (2014) "Great Expectations and the complexities of teacher development', English in Education 48 (1) 76-92

Vasquez, V. M. (2004) Negotiating Critical Literacies with Young Children. London: Routledge 